\title{
The Phenotypic and Genotypic Characteristics of Antibiotic Resistance in Escherichia coli Populations Isolated from Farm Animals with Different Exposure to Antimicrobial Agents
}

\author{
Department of Molecular Biology, Faculty of Biological Sciences, \\ University of Zielona Góra, Zielona Góra, Poland
}

JUSTYNA MAZUREK, PAWEŁ PUSZ, EWA BOK, MICHAŁ STOSIK and KATARZYNA BALDY-CHUDZIK

Received 27 July 2012, revised 7 December 2012, accepted 9 April 2013

\begin{abstract}
The aim of the study was to determine the influence of the presence or the absence of antibiotic input on the emergence and maintenance of resistance in commensal bacteria from food producing animals. The research material constituted E. coli isolates from two animal species: swine at different age from one conventional pig farm with antibiotic input in young pigs and from beef and dairy cattle originated from organic breeding farm. The sensitivity to 16 antimicrobial agents was tested, and the presence of 15 resistance genes was examined. In E. coli from swine, the most prevalent resistance was resistance to streptomycin (88.3\%), co-trimoxazole (78.8\%), tetracycline (57.3\%) ampicillin (49.3\%) and doxycycline (44.9\%) with multiple resistance in the majority. The most commonly observed resistance genes were: $b l a_{T E M}(45.2 \%)$, tetA (35.8\%), aadA1 (35.0\%), sul3 (29.5\%), dfrA1 (20.4\%). Differences in phenotypes and genotypes of E. coli between young swine undergoing prevention program and the older ones without the antibiotic pressure occurred. A disparate resistance was found in E. coli from cattle: cephalothin (36.9\%), cefuroxime (18.9\%), doxycycline (8.2\%), nitrofurantoin (7.7\%), and concerned mainly dairy cows. Among isolates from cattle, multidrug resistance was outnumbered by resistance to one or two antibiotics and the only found gene markers were: $b l a_{S H V}(3.4 \%)$, tet $A(1.29 \%), b l a_{T E M}(0.43 \%)$ and $\operatorname{tet} C(0.43 \%)$. The presented outcomes provide evidence that antimicrobial pressure contributes to resistance development, and enteric microflora constitutes an essential reservoir of resistance genes.
\end{abstract}

Ke y words: Escherichia coli, antibiotic resistance, resistance genes, animal production

\section{Introduction}

The increase of antibiotic resistance raises general concerns. Research focuses mainly on clinically important cases, nonetheless this issue involves all environmental areas. Escherichia coli is a commensal bacterium with primary habitat in the intestinal tract of humans and animals like swine, cattle and poultry which are used for food production (Hammerum and Heuer, 2009). E. coli can possess some virulence factors that allow a variety of intestinal and extraintestinal infections to appear, such as diarrhea, urinary tract infection, meningitis, septicemia or pneumonia both in humans and animals (Donnenberg et al., 2002; Hammerum and Heuer, 2009; Smith et al., 2007; Touchon et al., 2009). The significance of E. coli as a health hazard also arises from its dissemination capabilities. Strains from food-producing animals can contaminate meat products during slaughter, can survive a few days in a chiller and enter the food chain (Delsol et al., 2010; Tw et al., 2010). Various studies have demonstrated that resistant strains of animal origin are able to colonize or cause human infections (Aarestrup et al., 2008; Bélanger et al., 2011; Collignon et al., 2009; Manges and Johnson, 2012). The source of this problem can be food animal production systems. Intense application of antibiotics in conventional breeding of food animals, and also the volume of meat production results in the fact that the commensal flora in animals intestinal track constitutes an essential reservoir of resistance genes. Transfer of resistance determinants by mobile genetic elements is an important factor that can contribute to an increase in multiresistant bacteria (Blake et al., 2003). Organic breeding of food animals differs from conventional in many ways. In general, organic breeding standards prohibit the use of chemical fertilizers, chemicals and pharmaceuticals. Organic farming is based on the support of 'natural processes' in their production systems. The aim of this study was to compare the impact of conventional and organic animal production systems on the emergence and the development of resistance in E. coli strains.

* Corresponding author: J. Mazurek, Department of Molecular Biology, Faculty of Biological Sciences, University of Zielona Góra, Zielona Góra, Poland; e-mail: j.mazurek@wnb.uz.zgora.pl 


\section{Experimental}

\section{Materials and Methods}

Source of isolates. E. coli isolates from fecal samples derived from cattle and swine constituted the research material. Cattle (84 individuals) came from organic breeding farm and were classified into three distinct populations: two herds of beef cows feeding on pastures (labeled: I, II) and dairy cows housed in a barn. Swine derived from one conventional farm were represented by four age groups (25 individuals in each): group I comprised 6-week-old piglets (called piglets I), group II included 8-week-old piglets (piglets II), group III comprised 5-month-old sows (sows I), and group IV comprised 7-month-old sows (sows II). Conventional swine farming includes a post-weaning medical program involving treatment with sulfonamide, co-trimoxazole (trimethoprim/sulfamethoxazole) and ampicillin. The program was applied to all individuals in their $6^{\text {th }}$ week.

Isolation and identification. E. coli was isolated from feces and identification was carried out with biochemical testing, also BOX-PCR fingerprinting was conducted (Baldy-Chudzik and Stosik, 2007). The final material for the study consisted of 274 non-identical E. coli isolates from swine and 233 from cattle.

Antimicrobial susceptibility testing. Antibiotic sensitivity was determined using disc diffusion method on Mueller Hinton agar (Merck), following CLSI standards (CLSI, 2010). E. coli ATCC 25922 was used as a reference strain. The following antibiotics were tested: ampicillin $(10 \mu \mathrm{g})$, amoxicillin/ clavulanic acid

Table I

PCR conditions for detection antimicrobial resistance genes in E. coli isolates.

\begin{tabular}{|c|c|c|c|c|c|c|}
\hline Target gene & $\begin{array}{c}\text { Primer } \\
\text { name }\end{array}$ & Primer sequence $\left(5^{\prime}-3^{\prime}\right)$ & $\begin{array}{c}\text { Primer } \\
\text { concentration }\end{array}$ & $\begin{array}{c}\text { Annealing } \\
\text { temperature }\left({ }^{\circ} \mathrm{C}\right)\end{array}$ & $\begin{array}{l}\text { Product } \\
\text { size (bp) } \\
\end{array}$ & Reference \\
\hline$b l a_{\mathrm{TEM}}$ & $\begin{array}{l}\text { GKTEM-F } \\
\text { GKTEM-R }\end{array}$ & $\begin{array}{l}\text { TTAACTGGCGAACTACTTAC } \\
\text { GTCTATTTCGTTCATCCATA }\end{array}$ & $0,2 \mu \mathrm{M}$ & 55 & 247 & Kozak et al., 2009 \\
\hline$b l a_{\mathrm{SHV}}$ & $\begin{array}{l}\text { SHV-F } \\
\text { SHV-R }\end{array}$ & $\begin{array}{l}\text { AGGATTGACTGCCTTTTTG } \\
\text { ATTTGCTGATTTCGCTCG }\end{array}$ & $0,4 \mu \mathrm{M}$ & 55 & 393 & Kozak et al., 2009 \\
\hline$b l a_{\mathrm{CMY}-2}$ & $\begin{array}{l}\text { CMY- F } \\
\text { CMY-R }\end{array}$ & $\begin{array}{l}\text { GACAGCCTCTTTCTCCACA } \\
\text { TGGACACGAAGGCTACGTA }\end{array}$ & $0,2 \mu \mathrm{M}$ & 55 & 1000 & Kozak et al., 2009 \\
\hline tet $A$ & $\begin{array}{l}\text { Tet A-F } \\
\text { Tet A-R }\end{array}$ & $\begin{array}{l}\text { GCTACATCCTGCTTGCCTTC } \\
\text { CATAGATCGCCGTGAAGAGG }\end{array}$ & $0,2 \mu \mathrm{M}$ & 60 & 210 & Ng et al., 2001 \\
\hline tet $B$ & $\begin{array}{l}\text { Tet B-F } \\
\text { Tet B-R }\end{array}$ & $\begin{array}{l}\text { TTGGTTAGGGGCAAGTTTTG } \\
\text { GTAATGGGCCAATAACACCG }\end{array}$ & $0,2 \mu \mathrm{M}$ & 60 & 659 & Ng et al., 2001 \\
\hline tet $C$ & $\begin{array}{l}\text { Tet C-F } \\
\text { TetC-R }\end{array}$ & $\begin{array}{l}\text { CTTGAGAGCCTTCAACCCAG } \\
\text { ATGGTCGTCATCTACCTGCC }\end{array}$ & $0,2 \mu \mathrm{M}$ & 60 & 418 & Ng et al., 2001 \\
\hline tet $D$ & $\begin{array}{l}\text { Tet D-F } \\
\text { Tet D- R }\end{array}$ & $\begin{array}{l}\text { AAACCATTACGGCATTCTGC } \\
\text { GACCGGATACACCATCCATC }\end{array}$ & $0,2 \mu \mathrm{M}$ & 60 & 787 & Ng et al., 2001 \\
\hline tet $M$ & $\begin{array}{l}\text { Tet M- F } \\
\text { Tet M- R }\end{array}$ & $\begin{array}{l}\text { GTGGACAAAGGTACAACGAG } \\
\text { CGGTAAAGTTCGTCACACAC }\end{array}$ & $0,2 \mu \mathrm{M}$ & 58 & 406 & Ng et al., 2001 \\
\hline $\operatorname{aadA1}$ & $\begin{array}{l}\text { aadA- F } \\
\text { aadA-R }\end{array}$ & $\begin{array}{l}\text { GTGGATGGCGGCCTGAAGCC } \\
\text { AATGCCCAGTCGGCAGCG }\end{array}$ & $0,1 \mu \mathrm{M}$ & 63 & 525 & Kozak et al., 2009 \\
\hline $\operatorname{str} A / \operatorname{str} B$ & $\begin{array}{l}\text { strA-F } \\
\text { strB-R }\end{array}$ & $\begin{array}{l}\text { ATGGTGGACCCTAAAACTCT } \\
\text { CGTCTAGGATCGAGACAAAG }\end{array}$ & $0,4 \mu \mathrm{M}$ & 63 & 893 & Kozak et al., 2009 \\
\hline $\operatorname{aac}(3) I V$ & $\begin{array}{l}\text { aac4-F } \\
\text { aac4-R }\end{array}$ & $\begin{array}{l}\text { TGCTGGTCCACAGCTCCTTC } \\
\text { CGGATGCAGGAAGATCAA }\end{array}$ & $0,2 \mu \mathrm{M}$ & 63 & 653 & Kozak et al., 2009 \\
\hline sul1 & $\begin{array}{l}\text { sul1-F } \\
\text { sul1-R }\end{array}$ & $\begin{array}{l}\text { CGGCGTGGGCTACCTGAACG } \\
\text { GCCGATCGCGTGAAGTTCCG }\end{array}$ & $0,2 \mu \mathrm{M}$ & 66 & 433 & Kozak et al., 2009 \\
\hline sul2 & $\begin{array}{l}\text { sul2-L } \\
\text { sul2-R }\end{array}$ & $\begin{array}{l}\text { CGGCATCGTCAACATAACCT } \\
\text { TGTGCGGATGAAGTCAGCTC }\end{array}$ & $0,3 \mu \mathrm{M}$ & 66 & 721 & Kozak et al., 2009 \\
\hline sul3 & $\begin{array}{l}\text { sul3-GKa-F } \\
\text { sul3-GKa-R }\end{array}$ & $\begin{array}{l}\text { CAACGGAAGTGGGCGTTGTGGA } \\
\text { GCTGCACCAATTCGCTGAACG }\end{array}$ & $0,2 \mu \mathrm{M}$ & 66 & 244 & Kozak et al., 2009 \\
\hline$d f r A 7 / d f r A 17$ & $\begin{array}{l}\text { DFRA7- F } \\
\text { DFRA7-R }\end{array}$ & $\begin{array}{l}\text { CAGAAAATGGCGTAATCG } \\
\text { TCACCTTCAACCTCAACG }\end{array}$ & $0,2 \mu \mathrm{M}$ & 50 & 345 & Frech et al., 2003 \\
\hline$d f r A 1$ & $\begin{array}{l}\text { DFRA1-F } \\
\text { DFRA1-R }\end{array}$ & $\begin{array}{l}\text { GATATTCCATGGAGTGCCA } \\
\text { ACCCTTTTGCCAGATTTG }\end{array}$ & $0,2 \mu \mathrm{M}$ & 50 & 414 & Frech et al., 2003 \\
\hline
\end{tabular}

The multiplex PCR were performed for: 1- $b l a_{\mathrm{TEM}}, b l a_{\mathrm{SH}} b l a_{\mathrm{CMY}-2}, 2-\operatorname{tetB}$, tetC, tetD, 3- aadA1, strA/strB, aac(3)IV, 4- sul1, sul2, sul3. 
$(20 / 10 \mu \mathrm{g})$, cephalothin $(30 \mu \mathrm{g})$, cefuroxime $(30 \mu \mathrm{g})$, cefoperazone $(75 \mu \mathrm{g})$, ceftazidime ( $30 \mu \mathrm{g})$, streptomycin $(10 \mu \mathrm{g})$ neomycin $(30 \mu \mathrm{g})$, amikacin $(30 \mu \mathrm{g})$, gentamicin $(10 \mu \mathrm{g})$ tetracycline $(30 \mu \mathrm{g})$, doxycycline $(30 \mu \mathrm{g})$, chloramphenicol $(30 \mu \mathrm{g})$, nitrofurantoin $(300 \mu \mathrm{g})$ trimethoprim/sulfamethoxazole $(1.25 / 23.75 \mu \mathrm{g})$, norfloxacin $(10 \mu \mathrm{g})$ (Becton Dickinson).

Identification of resistance genes. The presence of resistance genes to $\beta$-lactam antibiotics: $b l a_{\mathrm{TEM}}, b l a_{\mathrm{SHV}}$, and $b l a_{\mathrm{CMY}-2}$, tetracycline resistance genes: tet $A$, tet $B$, tet $C$, tet $D$, tet $M$, streptomycin: $\operatorname{str} A / \operatorname{str} B, \operatorname{aac}(3) I V$ and aadA1, sulfonamides: sul1, sul2, sul 3 and trimethoprim: $d f r A 1$ and $d f r A 7 / d f r A 17$ was detected by PCR. The primers sequences, their final concentration, PCR annealing temperatures, and the amplicon sizes are listed in Table I (Kozak et al., 2009; Ng et al., 2001; Frech et al., 2003). PCR assays in $25 \mu \mathrm{l}$ final volume, contained: $2.5 \mu \mathrm{l}$ $10 \times$ PCR buffer, $2 \mathrm{mM} \mathrm{MgCl}, 0.25 \mathrm{mM}$ dNTP (Promega), $1 \mu \mathrm{l}$ Taq polymerase $2 \mathrm{U}$ (Fermentas) and $1,5 \mu \mathrm{l}$ DNA template (thermal lysates). Amplification program for the tet genes detection was as fallowed: initial denaturation at $94^{\circ} \mathrm{C} / 5 \mathrm{~min}, 35$ cycles: $94^{\circ} \mathrm{C} / 1 \mathrm{~min}$, annealing $/ 30 \mathrm{~s}, 72^{\circ} \mathrm{C} / 1 \mathrm{~min}$ and final extension $72^{\circ} \mathrm{C} / 5 \mathrm{~min}$, and for the remaining genes: $94^{\circ} \mathrm{C} / 10 \mathrm{~min}, 30$ cycles $94^{\circ} \mathrm{C} / 30 \mathrm{~s}$, annealing $/ 1 \mathrm{~min}$ and $72^{\circ} \mathrm{C} / 30 \mathrm{~s}$, with final extension $72^{\circ} \mathrm{C} / 10 \mathrm{~min}$. Amplicons were separated electrophoretically in $1.5 \%$ agarose $(1 \times \mathrm{TBE})$, stained by ethidium bromide and documented (BioCapt). PCR products were also sequenced (Genomed) and com- pered to GenBank data base. The accession numbers were: bla ${ }_{\mathrm{TEM}} \mathrm{GB}: J \mathrm{~J} 416149.1, b_{\mathrm{SHV}} \mathrm{GB}: \mathrm{AF} 148850.1$, tetA GB:FN554766.1, tetB GB:HQ333262.1, tetC GB:EU751610.1, aadA1 GB:JN596280.1, strA/strB FJ474091.2 sul1 GB: JN003421.1, sul2 GB:HQ018801.1, sul3 GB: HQ875012.1, dfrA1 GB:JN108887.1, dfrA7/ dfrA17 GB:JN108894.1.

Statistical analysis. Pearson's Chi squared test was used for determining the correlations between resistance genes prevalence and the source of E. coli origin with significance level set at $\mathrm{p}<0.05$ (statistical program $R$ version 2.15.0) (Verzani, 2005).

\section{Results}

Susceptibility of E. coli strains was diversified both between different host species and within groups of animals (between young and adult swine and between groups of cattle from pastures and dairy cows from barn), whereas the outcomes from similar populations (of two groups of piglets, sows and cattle herds) were comparable. Sensitivity to all tested agents demonstrated only $3.6 \%$ of E. coli from pigs but $43.8 \%$ from cattle isolates. Resistance to streptomycin (88.3\%), cotrimoxazole (78.8\%), tetracycline (57.3\%) and ampicillin (49.3\%) was dominant among isolates from swine (Table II). In the total set of E. coli from swine, $81.0 \%$ of isolates were resistant to 3 or more antibiotics

Table II

Occurrence of antimicrobial resistance among E. coli isolated from group of swine and cattle.

\begin{tabular}{|l|r|r|r|r|r|r|r|r|r|}
\hline \multirow{2}{*}{ Antibiotic } & \multicolumn{9}{|c|}{ No. (\%) of resistant isolates from: } \\
\cline { 2 - 11 } & $\begin{array}{c}\text { Piglets I } \\
\mathrm{n}=59\end{array}$ & $\begin{array}{c}\text { Piglets II } \\
\mathrm{n}=51\end{array}$ & $\begin{array}{c}\text { Sows I } \\
\mathrm{n}=78\end{array}$ & $\begin{array}{c}\text { Sows II } \\
\mathrm{n}=86\end{array}$ & $\begin{array}{c}\text { Total in } \\
\text { swine } \\
\mathrm{n}=274\end{array}$ & $\begin{array}{c}\text { Cattle } \\
\text { pasture I } \\
\mathrm{n}=58\end{array}$ & $\begin{array}{c}\text { Cattle } \\
\text { pasture II } \\
\mathrm{n}=50\end{array}$ & $\begin{array}{c}\text { Cattle } \\
\text { barn } \\
\mathrm{n}=125\end{array}$ & $\begin{array}{c}\text { Total } \\
\text { in cattle } \\
\mathrm{n}=233\end{array}$ \\
\hline Ampicillin & $50(84.7)$ & $42(82.4)$ & $18(23.1)$ & $25(29.1)$ & $135(49.3)$ & $1(1.7)$ & $0(0)$ & $8(6.4)$ & $9(3.9)$ \\
\hline $\begin{array}{l}\text { Amoxicillin/ } \\
\text { Clavulanic Acid }\end{array}$ & $4(6.8)$ & $0(0.0)$ & $0(0.0)$ & $0(0.0)$ & $4(1.5)$ & $2(3.4)$ & $0(0)$ & $11(8.8)$ & $13(5.6)$ \\
\hline Cephalothin & $37(62.7)$ & $44(86.3)$ & $23(29.5)$ & $17(19.8)$ & $121(44.2)$ & $16(27.6)$ & $9(18)$ & $61(48.8)$ & $86(36.9)$ \\
\hline Cefuroxime & $5(8.5)$ & $3(5.9)$ & $0(0.0)$ & $0(0.0)$ & $8(2.9)$ & $7(12.1)$ & $5(10)$ & $32(25.6)$ & $44(18.9)$ \\
\hline Cefoperazone & $4(6.8)$ & $3(5.9)$ & $0(0.0)$ & $0(0.0)$ & $7(2.6)$ & $0(0)$ & $0(0)$ & $3(2.4)$ & $3(1.3)$ \\
\hline Ceftazidime & $5(8.5)$ & $0(0.0)$ & $0(0.0)$ & $0(0.0)$ & $5(1.8)$ & $1(1.7)$ & $0(0)$ & $7(5.6)$ & $8(3.4)$ \\
\hline Streptomycin & $57(96.6)$ & $51(100)$ & $64(82.1)$ & $70(81.4)$ & $242(88.3)$ & $3(5.2)$ & $0(0)$ & $5(4.0)$ & $8(3.4)$ \\
\hline Neomycin & $2(3.4)$ & $0(0.0)$ & $1(1.3)$ & $2(2.3)$ & $5(1.8)$ & $0(0)$ & $0(0)$ & $1(0.8)$ & $1(0.4)$ \\
\hline Amikacin & $0(0.0)$ & $0(0.0)$ & $2(2.6)$ & $0(0.0)$ & $2(0.7)$ & $1(1.7)$ & $1(2)$ & $10(8.0)$ & $12(5.2)$ \\
\hline Gentamicin & $21(35.6)$ & $17(33.3)$ & $1(1.3)$ & $1(1.2)$ & $40(14.6)$ & $1(1.7)$ & $0(0)$ & $13(10.4)$ & $14(6.0)$ \\
\hline Tetracycline & $47(79.7)$ & $33(64.7)$ & $41(52.6)$ & $36(41.9)$ & $157(57.3)$ & $0(0)$ & $0(0)$ & $3(2.4)$ & $3(1.3)$ \\
\hline Doxycycline & $31(52.5)$ & $24(47.1)$ & $36(46.2)$ & $32(37.2)$ & $123(44.9)$ & $4(6.9)$ & $0(0)$ & $15(12)$ & $19(8.2)$ \\
\hline Chloramphenicol & $34(57.6)$ & $21(41.2)$ & $30(38.5)$ & $26(30.2)$ & $111(40.5)$ & $3(5.2)$ & $3(6)$ & $6(4.8)$ & $12(5.2)$ \\
\hline Nitrofurantoin & $8(13.6)$ & $2(3.9)$ & $5(6.4)$ & $0(0)$ & $15(5.5)$ & $2(3.4)$ & $0(0)$ & $16(12.8)$ & $18(7.7)$ \\
\hline $\begin{array}{l}\text { Trimethoprim/ } \\
\text { Sulfamethoxazole }\end{array}$ & $56(94.9)$ & $47(92.2)$ & $50(64.1)$ & $63(73.3)$ & $216(78.8)$ & $1(1.7)$ & $1(2)$ & $2(1.6)$ & $4(1.7)$ \\
\hline Norfloxacin & $1(1.7)$ & $0(0.0)$ & $1(1.3)$ & $0(0.0)$ & $2(0.7)$ & $0(0)$ & $3(6)$ & $0(0)$ & $3(1.3)$ \\
\hline
\end{tabular}


Table III

Occurrence of multidrug resistance among E. coli isolated from groups of swine and cattle.

\begin{tabular}{|l|r|r|r|r|r|r|r|r|r|}
\hline \multirow{2}{*}{ Multiresistance } & \multicolumn{9}{|c|}{ Pumber (\%) of isolates derived from } \\
\cline { 2 - 11 } & \multicolumn{4}{|c|}{ Pigs } & \multicolumn{5}{c|}{ Cattle } \\
\hline & $\begin{array}{c}\text { Piglets I } \\
\mathrm{n}=59\end{array}$ & $\begin{array}{c}\text { Piglets II } \\
\mathrm{n}=51\end{array}$ & $\begin{array}{c}\text { Sows I } \\
\mathrm{n}=78\end{array}$ & $\begin{array}{c}\text { Sows II } \\
\mathrm{n}=86\end{array}$ & $\begin{array}{c}\text { Total } \\
\mathrm{n}=274\end{array}$ & $\begin{array}{c}\text { Pasture I } \\
\mathrm{n}=58\end{array}$ & $\begin{array}{c}\text { Pasture II } \\
\mathrm{n}=50\end{array}$ & $\begin{array}{c}\text { Barn } \\
\mathrm{n}=125\end{array}$ & $\begin{array}{c}\text { Total } \\
\mathrm{n}=233\end{array}$ \\
\hline Resistant to 1 antibiotic & $1(1,7)$ & $0(0)$ & $8(10,3)$ & $12(14,0)$ & $21(7,7)$ & $15(25,9)$ & $4(8,0)$ & $37(29,6)$ & $66(28,3)$ \\
\hline Resistant to 2 antibiotics & $2(3,4)$ & $0(0)$ & $11(14,1)$ & $8(9,3)$ & $21(7,7)$ & $10(17,2)$ & $0(0)$ & $17(13,6)$ & $31(13,3)$ \\
\hline Resistant to 3 or more antibiotics & $56(94,9)$ & $51(100,0)$ & $55(70,5)$ & $60(69,8)$ & $222(81,0)$ & $2(3,4)$ & $0(0)$ & $32(25,6)$ & $34(14,6)$ \\
\hline Sensitive & $0(0)$ & $0(0)$ & $4(5,1)$ & $6(7,0)$ & $10(3,6)$ & $31(53,4)$ & $14(28,0)$ & $39(31,2)$ & $102(43,8)$ \\
\hline
\end{tabular}

(Table III). Resistance to the majority of the tested antibiotics decreased with the age of the swine, and the ratio of resistance decrease (except for gentamicin) remained on a similar level.
Isolates from cattle demonstrated the highest resistance to cephalothin (36.9\%), cefuroxime (18.9\%), doxycycline $(8.2 \%)$ and nitrofurantoin $(7.7 \%)$ (Table II). Generally, lower resistance levels were observed in
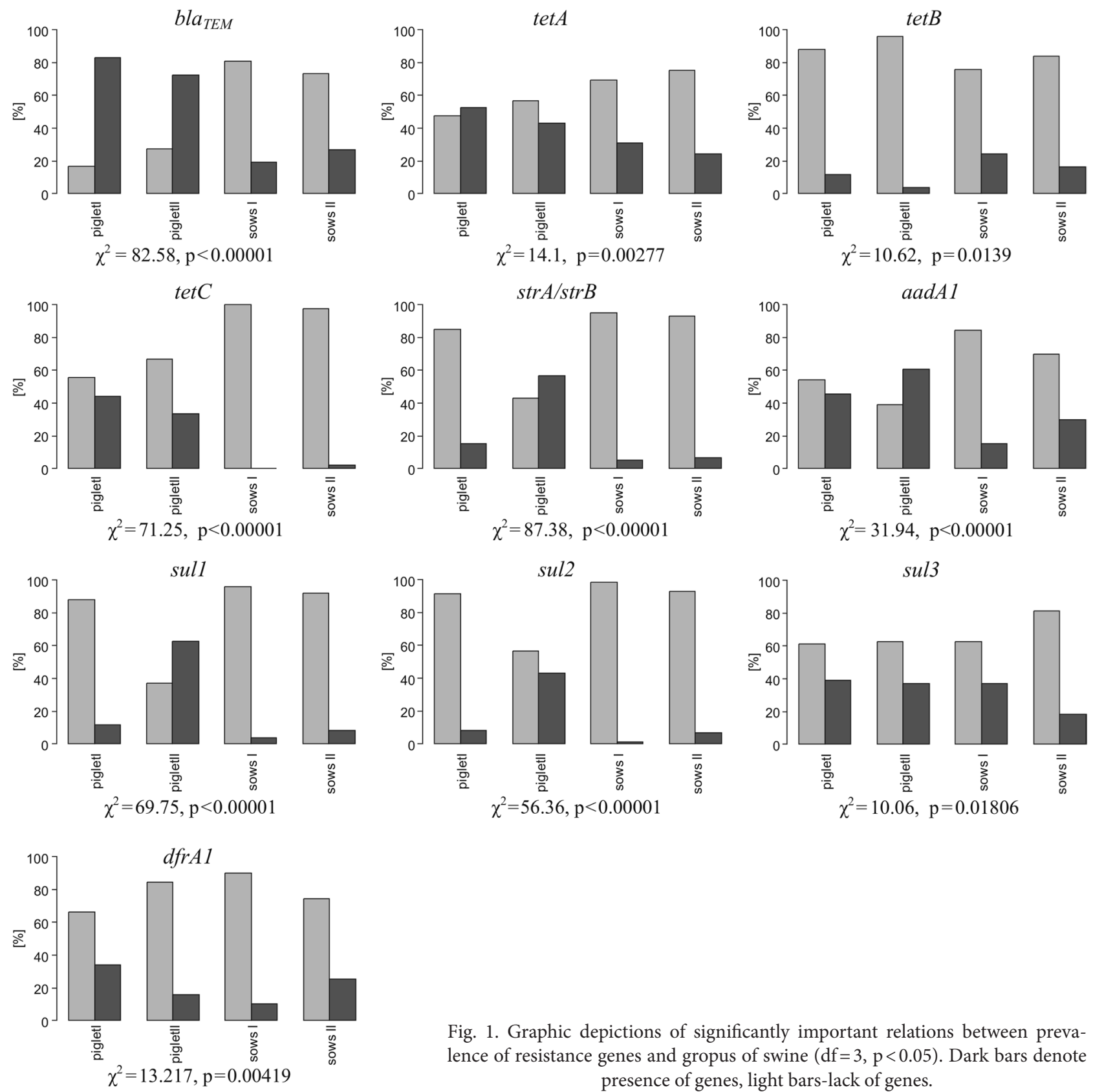

Fig. 1. Graphic depictions of significantly important relations between prevalence of resistance genes and gropus of swine $(\mathrm{df}=3, \mathrm{p}<0.05)$. Dark bars denote presence of genes, light bars-lack of genes. 


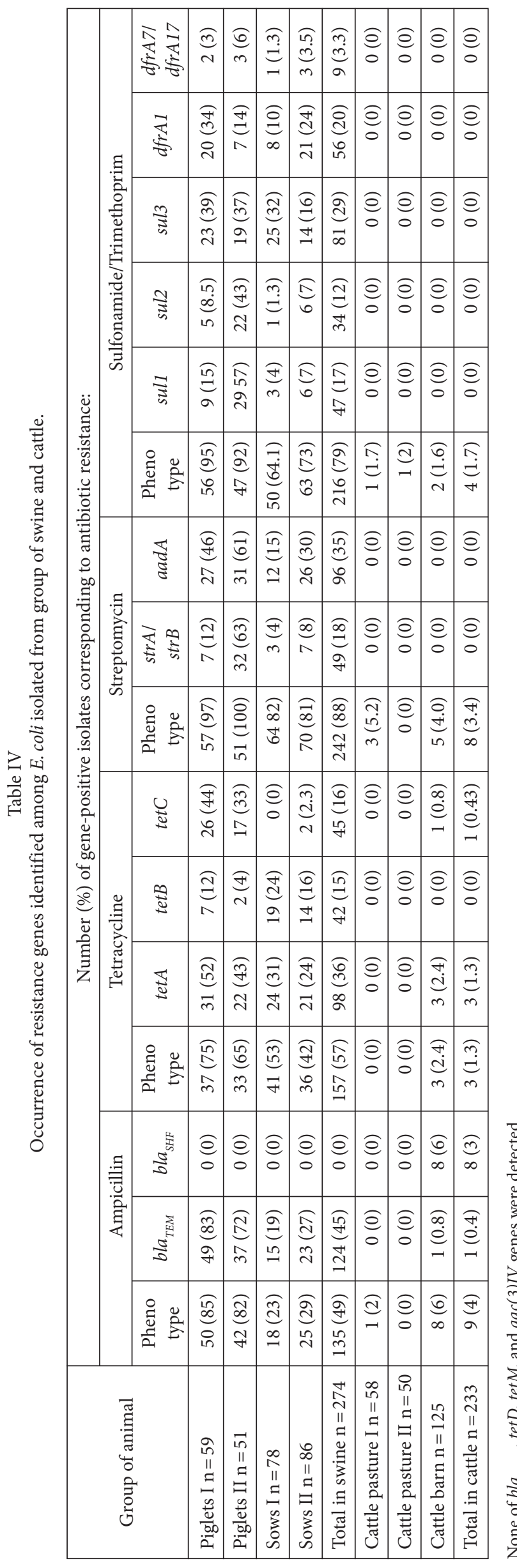

isolates from cattle living on pastures than housed in a barn and multidrug resistance concerned mainly E. coli from dairy cows (Table III).

All the phenotypically resistant isolates were tested for the presence of the resistance genes. The most commonly identified gene in isolates from swine was $b l a_{T E M^{\prime}}$ then tet $A$, aadA1, sul3, dfrA1, strA/strB, sul1, tet $C$, tet $B$, sul 2 and $d f r A 7 / d f r A 17$ (Table IV), and differences in the prevalence of resistance genes between $E$. coli from piglets and sows were observed. The results of Pearson's Chi squared tests indicated a significant relation between the prevalence of resistance genes in commensal E. coli from swine and the age group of these animals (Fig. 1). The distribution of bla ${ }_{\text {TEM }}$ tet $A$ and tetC genes in E. coli decreased with the age of the swine, but for tet $B$ gene the decrease occurred separately in isolates derived from young and adult pigs. For the $\operatorname{str} A / \operatorname{str} B$, aadA1, sull and sul2 genes the prevalence increased in E. coli from piglets, but decreased in sows (Fig. 1). The relation of the prevalence of sul 3 and $d f r A 1$ genes was maintained at a similar levels in isolates from the analyzed groups of swine. For $d f r A 7 / d f r A 17$ gene differences in occurring were not statistically significant $(\mathrm{p}=0.5557)$. Predominant resistance gene profiles were different for isolates from various groups of swine. More complex resistance gene profiles (consisting of 2 to 6 genes) were found in strains from piglets., whereas simpler profiles occurred in strains from sows. The most commonly observed resistance genotype patterns are placed in Table V. None of the examined genes were found in E. coli from beef cows feeding on pastures, but 8 bla ${ }_{S H V}, 1 \mathrm{bla}_{\mathrm{TEM}}, 2$ tet $A$, and 1 combination of tet $A+\operatorname{tet} C$ genes were identified in E. coli from dairy cows housed in the barn.

\section{Discussion}

The results of research concerning relations between antibiotic input and resistance development vary in terms of geographic location, bacterial species and antimicrobials tested (Jacob et al., 2008). Few studies have examined conventional and organic breeding. In conventional production on a large scale, antibiotic usage is a part of the production system, not only in veterinary practice, but also as a prophylactic measure, on account of numerous illnesses. Gastrointestinal and respiratory infections are very common, especially in piglets during their weaning period, and E. coli is one of the pathogens (Aarestrup et al., 2008). Cattle are less sensitive to illnesses, thus there is no need to administer preventive antibiotic supplements and it is mainly dairy cows with mastitis that require treatment.

The presented data demonstrate a relationship between selective pressure of antibiotic and the emergence of resistance. Antibiotic resistance patterns 
Table $\mathrm{V}$

The most commonly detected gene patterns in E. coli isolates from groups of swine.

\begin{tabular}{|c|c|c|c|}
\hline Piglets I & Piglets II & Sows I & Sows II \\
\hline$b l a_{T E M}$, tet $A / B / C$ & bla $a_{T E M}, t e t C, \operatorname{str} A / B$, aadA 1, sull, sul3 & tet $B$ & $b l a_{T E M}$ \\
\hline bla $a_{T E M}$, tet $A$, tet $C$ & tet $A, \operatorname{str} A / B$, aad $A 1, \operatorname{sul1} / 2, d f r A 1$ & sul3 & tet $A$ \\
\hline bla $_{T E M}$, tet $A /$ tet $C$, sul3 & $b l a_{T E M}$, tet $C$, sul3 & tet $A$ & tetB \\
\hline bla $_{T E M}$, tet $B / C, \operatorname{str} A / B$, aad $A 1$, sul3 & bla $_{T E M}$, sul2 & tet $A /$ tetB, sul1/3 & aadA1 \\
\hline bla $_{T E M}$, tetC aadA1, sul1, sul2, dfrA1 & $b l a_{T E M}, \operatorname{str} A / B, \operatorname{aad} A 1, \operatorname{sul} 1 / 2 / 3$ & bla $_{\text {TEM }}$, tet $A /$ tet $B$, sull $/ 3$ & tet $A /$ tet $B, d f r A 1$ \\
\hline
\end{tabular}

differed between E. coli from different hosts, from very high resistance levels in swine isolates to low frequency of resistance in E. coli from cattle. The occurrence of high resistance to co-trimoxazole and ampicillin in piglets was the consequence of antibiotic supply in their post-weaning period. In older pigs (sows I, II) with no antibiotic pressure, resistance to these agents decreased: slightly to co-trimazol ( $93.6 \%$ in piglets vs. $68.9 \%$ in sows) and significantly to ampicillin (83.6\% in piglets vs. $26.2 \%$ in sows) but still remained. Very high resistance levels and multiple resistances up to 9 agents were observed, with great proportion for aminoglycosides (streptomycin) and tetracyclines. These antibiotics are used in veterinary treatment, but the subject animals were not treated with these agents. That clearly indicates the accumulation of resistance gene cassettes and dissemination in population. The presented data show that E. coli from pigs share a similar gene pool. Additionally, great dynamics of their appearance was found, which reflects different genetic patterns, beginning with a single resistance gene detected in isolates from sows up to complex patterns containing 6 genes in isolates from piglets. The prevalence of resistance genes corresponding to $\beta$-lactam antibiotics $\left(b l a_{T E M}\right)$ and tetracyclines (tet $A$ and tet $C$ ) decreased along with the age of the swine. Resistance to streptomycin stayed on high level, but the dissemination of corresponding resistance genes altered. The increase in frequency of $\operatorname{str} A / \operatorname{str} B$ and aadA 1 gene was observed in strains from piglets during antibiotic administration (medical preventive program), whereas lower dissemination was observed in isolates from sows. The high resistance to co-trimazole was found in E. coli from all analyzed groups of swine, and the prevalence of resistance genes dfrA 1 and sul 3 was also identified. However, the frequency of sul1 and sul2 resistance genes increased in piglets and decreased in sows.

The predominant resistant genotype revealed in this research in E. coli from swine (bla ${ }_{T E M}$, tetA, aadA1, sul3, $d f r A 1)$ was different from that observed by Kozak et al. in Canada (2009), where the most commonly detected genes were, in order of decreasing prevalence: tet $B$, aadA1, $\operatorname{str} A / \operatorname{str} B$, tet $A$. Also dissimilar results (tet $D$, tet $A, d f r A 1, \operatorname{aad} A 1, \operatorname{str} A / \operatorname{str} B$ ) were received by Frye et al. (2011), where E. coli from pigs in Georgia (USA) was examined. In this study the tetracycline resistance genes tet $A$ and $t e t B$ were the most frequently identified in E. coli from adult swine and cattle and this stayed in agreement with the outcomes of other research referring to the intestinal bacteria of food animals, pigs and cattle (Bryan et al., 2004; Sengeløv et al., 2003).

The research revealed that the resistance prevalence in E. coli from swine differed from the resistance prevalence found in isolates from cattle. Apart from crossresistance to cephalosporins, low resistance (under $10 \%)$ to the remaining antibiotics was observed. These low resistance rates illustrate the lack or only occasional occurrence of antibiotic pressure in these populations. In comparison to resistance genes prevalence in isolates from swine, very few resistance genes were identified in isolates from cattle. In E. coli from pigs, the resistance gene corresponding to resistance to $\beta$-lactam antibiotics was $b l a_{T E M}$, whereas in isolates from cattle it was gene $b l a_{\mathrm{SHV}^{*}}$ Contrary to these data, a few studies revealed high, multiple resistance with complex genetic patterns in isolates derived from cattle either from conventional farming or with the treatment applied (Guerra et al., 2003; Karczmarczyk et al., 2011). In the presented paper, phenotypic resistance and resistance genes were identified mainly in isolates from cows housed in the barn. This can be an effect of the dissemination of resistant strains from humans to animals. Several studies indicated that antimicrobial resistance rates are higher among animals with human exposure than on isolated areas with little contact with humans (Kozak et al., 2009; Skurnik et al., 2006). The presented research indicates that E. coli strains originating from herds of cows grazed on a pasture without any antibiotic pressure do not constitute meaningful reservoir of resistance genes.

Antibiotic administration in food-producing animals has resulted in greater breeding success in one aspect, but it contributes to resistance development, therefore these animals constitute the reservoir for antimicrobial resistance genes. The presented data confirm a link between exposure to antibiotics and resistance development. They indicate that once generated resistance can fluctuate but persists in a population. 
Acknowledgement 176340

The study was supported by a grant from the MNiSW nr N N304

\section{Literature}

Aarestrup F., H. Wegener and P. Collignon. 2008. Resistance in bacteria of the food chain: epidemiology and control strategies. Expert Rev Anti. Infect. Ther. 6: 733-750.

Baldy-Chudzik K. and M. Stosik. 2007. Prevalence of antibiotic resistance profile in relation to phylogenetic background among commensal Escherichia coli derived from various mammals. Pol. J. Microbiol. 56:175-183.

Bélanger L., A. Garenaux, J. Harel, M. Boulianne, E. Nadeau and C. Dozois. 2011. Escherichia coli from animal reservoirs as a potential source of human extraintestinal pathogenic E. coli. FEMS Immunol. Med. Microbiol. 62: 1-10.

Blake D., R. Humphry, K. Scott, K. Hillman, D. Fenlon and J. Low. 2003. Influence of tetracycline exposure on tetracycline resistance and the carriage of tetracycline resistance genes within commensal Escherichia coli populations. J. Appl. Microbiol. 94: 1087-1097. Bryan A., N. Shapir and M.J. Sadowsky. 2004. Frequency and distribution of tetracycline resistance genes in genetically diverse, nonselected, and nonclinical Escherichia coli strains isolated from diverse human and animal sources. Appl. Environ. Microbiol.70: 2503-2507. CLSI. 2010. Clinical and Laboratory Standards Institute, Performance Standards for Antimicrobial Susceptibility Testing; Twentieth Informational Supplement. CLSI Document M100-S20, Clinical and Laboratory Standards Institute, Wayne, PA.

Collignon P., J. Powers, T. Chiller, A. Aidara-Kane and F. Aarestrup. 2009. World health organization ranking of antimicrobials according to their importance in human medicine: A critical step for developing risk management strategies for the use of antimicrobials in food production animals. Clin. Infect. Dis. 49: 132-141.

Delsol A., D. Halfhide, M. Bagnall, L. Randall, V. Enne, M. Woodward and J. Roe. 2010. Persistence of a wild type Escherichia coli and its multiple antibiotic-resistant (MAR) derivatives in the abattoir and on chilled pig carcasses. Int. J. Food Microbiol. 140: 249-253.

Donnenberg M.S. 2002. Escherichia coli: Virulence mechanisms of a versatile pathogen. Elsevier ISBN: 978-0-12-220751-8.

Frech G., C. Kehrenberg and C.S. Schwarz. 2003. Resistance phenotypes and genotypes of multiresistant Salmonella enterica subsp. enterica serovar Typhimurium var. Copenhagen isolates from animal sources. J. Antimicrob. Chemother. 51: 180-182.

Frye J., R. Lindsey, R.J. Meinersmann, M.E. Berrang, C.R. Jackson, M.D. Englen, J.B. Turpin and P.J. Fedorka-Cray. 2011. Related antimicrobial resistance genes detected in different bacterial species coisolated from swine fecal samples. Foodborne Pathog. Dis. 8: 663-679. Guerra B., E. Junker, A. Schroeter, B. Malorny, S. Lehmann and R. Helmuth. 2003. Phenotypic and genotypic characterization of antimicrobial resistance in German Escherichia coli isolates from cattle, swine and poultry. J. Antimicrob. Chemother. 52: 489-492.

Hammerum A. and O. Heuer. 2009. Human health hazards from antimicrobial-resistant Escherichia coli of animal origin. Clin. Infect. Dis. 48: 916-921.

Jacob M., J. Fox, S. Reinstein and T. Nagaraja. 2008. Antimicrobial susceptibility of foodborne pathogens in organic or natural production systems: an overview. Foodborne Pathog. Dis. 5: 721-730.

Karczmarczyk M., C. Walsh, R. Slowey, N. Leonard and S. Fanning. 2011. Molecular characterization of multidrug-resistant Escherichia coli isolates from Irish cattle farms. Appl. Environ. Microbiol. 77: 7121-7127.

Kozak G., P. Boerlin, N. Janecko, R.J. Reid-Smith and C. Jardine. 2009. Antimicrobial resistance in Escherichia coli isolates from swine and wild small mammals in the proximity of swine farms and in natural environments in Ontario, Canada. Appl. Environ. Microbiol.75: 559-566.

Manges A. and J. Johnson. 2012. Foodborne origins of Escherichia coli causing extraintestinal infections. Clin. Infect. Dis. 55: 1310-1317.

Ng L.-K., I. Martin, M. Alfa and M. Mulvey. 2001. Multiplex PCR for the detection of tetracycline resistant genes. Mol. Cell. Probes 15: 209-215.

Sengeløv G., B. Halling-Sørensen and F. Aarestrup. 2003. Susceptibility of Escherichia coli and Enterococcus faecium isolated from pigs and broiler chickens to tetracycline degradation products and distribution of tetracycline resistance determinants in E. coli from food animals. Vet. Microbiol. 95: 91-101.

Skurnik D., R. Ruimy, A. Andremont, C. Amorin, P. Rouquet, B. Picard and E. Denamur. 2006. Effect of human vicinity on antimicrobial resistance and integrons in animal faecal Escherichia coli. J. Antimicrob. Chemother. 57: 1215-1219.

Smith J., P. Fratamico and N. Gunther. 2007. Extraintestinal pathogenic Escherichia coli. Foodborne Pathog. Dis. 4: 134-163.

Touchon M, C. Hoede, O. Tenaillon, V. Barbe, S. Baeriswyl, P. Bidet, E. Bingen, S. Bonacorsi, Ch. Bouchier, O. Bouvet, A. Calteau, H. Chiapello, O. Clermont, S. Cruveiller, A. Danchin, M. Diard, C. Dossat, M. El Karoui, E. Frapy, L. Garry, J.M. Ghigo, A.M. Gilles, J. Johnson, Ch. Le Bouguénec, M. Lescat, S. Mangenot, V. Martinez-Jéhanne, I. Matic, X. Nassif, S. Oztas, M. A. Petit, Ch. Pichon, Z. Rouy, C. Saint Ruf, D. Schneider, J. Tourret, B. Vacherie, D. Vallenet, C. Médigue, E. Rocha and E. Denamur. 2009. Organised genome dynamics in the Escherichia coli species results in highly diverse adaptive paths. PLoS Genet 5: e1000344; doi:10.1371/journal.pgen.1000344

Tw A., G. Inglis, L. Yanke, E. Topp, R. Read, T. Reuter and T. McAllister. 2010. Farm-to-fork characterization of Escherichia coli associated with feedlot cattle with a known history of antimicrobial use. Int. J. Food Microbiol. 137: 40-48.

Verzani J. 2005. Using R for Introductory Statistics, Chapman and Hall/CRC. ISBN/ASIN: 1584884509 ISBN-13: 9781584884507. 
